$\ulcorner$ The Sea $\lrcorner$ Journal of the Korean Society of Oceanography Vol. 19, No. 1, pp. 1 - 7, February 2014 http://dx.doi.org/10.7850/jkso.2014.19.1.1

\title{
Free Access
}

\section{울산만 퇴적물 내 유기주석화합물의 시공간적 분포 특성}

\author{
백승홍 · 최민규* · 이인석 · 이재환 · 황동운 · 김숙양 \\ 국립수산과학원 어장환경과
}

\section{Temporal and Spatial Distribution of Butyltin Compounds in Marine Sediments from Ulsan Bay, Korea}

\author{
Seung-Hong Baek, Minkyu ChOI*, In-Seok LeE, Jae-Hwan Lee, \\ DONG-WOON HWANG AND SOOK-YANG KIM \\ Marine Environment Research Division, National Fisheries Research and Development Institute (NFRDI), Busan 619-705, Korea
}

\begin{abstract}
Tribuyltin (TBT)을 포함한 유기주석 방오도료의 국내 사용규제에 따른 저감효과를 평가하기 위해서, 국내에서 가 장 큰 산업항 중 하나인 울산항 주변에서 2009년과 2011년에 채취한 퇴적물 내 유기주석화합물(butyltin compounds; $\mathrm{BTs}$ )을 정량하여 잔류수준과 공간적 분포를 조사하였다. 또한 2003년 조사결과와 비교하여 퇴적물 내 유기주석화합 물 잔류의 장기경향을 조사하였다. 퇴적물 내 TBT의 농도범위는 14.2 1204 ng Sn g-1 dry wt이었고, dibutyltin은 $19.5 \sim 980 \mathrm{ng} \mathrm{Sn} \mathrm{g}{ }^{-1} \mathrm{dry} w \mathrm{w}$ 을 보였다. BTs의 가장 높은 농도는 대형조선소 부근에서 조사되었고, 다음으로 높은 농 도는 울산항 컨테이너선 정박지 부근에서 조사되었다. 이것은 울산만에서 TBT의 가장 중요한 배출원은 선박활동을 포함한 해운산업과 관련 있음을 의미한다. 2003년, 2009년, 2011년의 BTs 농도를 비교한 결과, 퇴적물 내 TBT 농도는 유의한 수준으로 감소하고 있어서 국내 사용규제에 따른 저감 효과가 울산만에서도 나타나고 있었다. 해수와 생물 내 농도감소는 보고된 적이 있지만, 규제 이후 퇴적물에서 유기주석화합물의 농도감소는 이번 연구에서 처음 보고 되는 결과이다. 하지만, 퇴적물 내 BTs의 잔류수준은 생물학적 영향농도보다 높은 수준이었다. 따라서 울산만에서 유기주석화합물로 인한 오염에 대한 저감노력과 지속적인 모니터링이 필요하다.
\end{abstract}

Butyltin compounds (BTs) were determined in surface sediment samples from Ulsan Bay in 2009 and 2011, to assess the contamination status and the effectiveness of tributylin (TBT) restriction of Korea. Dibutyltin and TBT concentrations in sediments in 2011 ranged from 19.5 to 980 and 14.2 to $1204 \mathrm{ng} \mathrm{Sn} \mathrm{g}^{-1}$ dry weight, respectively. The highest TBT concentration was found in a big shipyard complex and the next highest was found in harbor, suggesting that harbor and shipyard activities are a major contamination source of TBT in Ulsan Bay. Concentrations of BTs in Ulsan Bay sediments were significantly lower in 2009 and 2011 than that in 2003 survey previously reported, probably as a consequence of the legislative action in Korea. However, TBT concentrations in sediments still exceeded ecotoxicological values. Therefore, it will be important to monitor and reduce TBT contamination in sediments until the levels fall well below ecotoxicological levels.

Key words: BTs, TBT, sediment, temporal trend, spatial distribution, Ulsan Bay

\section{서 론}

유기주석화합물(organotins) 중 트리부틸틴(tributyltin, TBT)은 선박이나 수중구조물에서 생물체의 부착을 방지하기 위한 도료의 첨가물로 사용되었다. 구조물 표면에서 용출된 $\mathrm{TBT}$ 는 부착성 생 물뿐만 아니라 주변 생물까지 다양한 악영향을 미쳐 생태계에 큰

Received September 5, 2013; Revised November 19, 2013; Accepted December 18, 2013 *Corresponding author: mkchoi3@korea.kr
교란현상을 일으켰다(홍 등, 2001). 해양생물에 대한 TBT의 위해 성이 보고된 1970년대 이후, 국제해사기구(International Maritime Organization)는 2008년부터 유기주석화합물 함유 방오도료의 사 용금지와 선체 잔존을 금지하였다(IMO, 2009). 우리나라도1999년 도부터 유해화학물질관리법에 의해 TBT의 사용을 규제하였으며, 이후 국제적 규제동향에 맞추어 TBT 함유 방오도료의 사용규제 및 금지(2003년 사용금지, 2008년 선체잔존금지)를 추진해왔다 (MOMAF, 2002; Choi et al., 2009b). TBT 사용규제가 시행된 이 
후, 국내 연안의 환경매체 중 해수와 생물 내 $\mathrm{TBT}$ 잔류수준은 감 소되는 경향으로 나타났으나, 매체의 특성의 차이로 퇴적물 내 $\mathrm{TBT}$ 잔류수준의 감소경향은 뚜렷하지 않은 것으로 보고되었다 (Choi et al., 2009a). 퇴적물 내 TBT 오염은 오랜 기간 해수와 생 물에 악영향을 미칠 수 있는 오염원으로 작용할 수 있으므로, 퇴 적물 내 TBT의 농도저감은 매우 중요하다(Shim et al., 2005; Choi et al., 2011).

퇴적물 내 $\mathrm{TBT}$ 의 높은 농도는 항만 및 조선소 등 선박활동이 빈번한 연안에서 보고되고 있으며, 국내 연안에서는 공업과 선박 시설이 위치한 울산항, 마산만, 고현만에서 고농도가 보고되었다 (Choi et al., 2009b). 특히, 울산항의 해수, 퇴적물, 생물에서 TBT 최고농도는 국내연안에서 최고수준으로 보고되기도 하였다(Choi et al., 2009a, b). 울산만은 항만시설(면적2,267,185 m²)이 있으며, 울산만 내 위치한 대형조선소는 1975년 설립 이후 년간 8000대 이상의 선박이 수리 및 보수되고 있는 것으로 알려져 있다(Shim et al., 2002). 또한, 해운화물 수송량이 입항과 출항 각각 101,196 천, 70,467 천 톤이며, 2010 년 어선의 보유량이 1280 척으로 상업 과 어업의 해상활동이 활발히 이루어지고 있는 해역이다(통계청, 울산광역시청 홈페이지). 이러한 울산만의 해상활동으로 발생되는 퇴적물 내 TBT 오염에 대한 연구는 Choi et al.(2009a), Shim et $a l .(2002)$ 등에 의해 수행되었으나, 선행연구는 2004 년 이전의 시 료를 분석한 결과들로 국내 TBT 규제 이후 최근 오염도에 대한 연구는 미비한 실정이다.

본 연구에서는 2009년과 2011년 채취한 울산만 퇴적물 내 TBT를 포함한 부틸틴화합물(butyltin compounds; BTs)를 분석하였으며, 이를 바탕으로 울산만 내 $\mathrm{BTs}$ 오염현황을 파악하였고, 동일정점에 대한 2003년 조사결과(Choi et al., 2009a)와 비교하여 울산만에 서 $\mathrm{TBT}$ 규제정책의 효과를 평가하였다. 또한 BTs는 퇴적물 내 잔 류성유기오염물질(persistent organic pollutants; POPs)과 상관성 분석을 통해 선박활동으로 인한 다른 독성물질의 기여도도 추정 하였다.

\section{재료 및 방법}

\section{조사정점 및 시료채취}

우리나라 남동해에 위치한 울산만은 연안을 따라 석유화학공단, 자동차 공장 등의 대형공장과 울산항, 조선소 등 선박시설이 위치 하고 있다(Fig. 1). 퇴적물 시료는 2009년과 2011년 울산만 연안의 13 개 정점(U1 U13)에서 채취하였고, 비교해역으로 외측 2 개 정 점(U14 U15)에서도 채취하였다. 퇴적물 시료는 van Veen grab sampler를 이용하여 표층 $(<4 \mathrm{~cm})$ 을 채취하였으며, 채취된 퇴적물 은 조사선 냉동실에서 냉동하여 실험실로 운반한 후 동결건조하 여 전처리하였다.

\section{시료전처리 및 기기분석}

퇴적물 중 BTs는 Choi et al.(2010) 분석방법에 따라 수행하였 다. 동결건조된 퇴적물 시료 $2 \sim 3 \mathrm{~g}$ 을 $50 \mathrm{~mL}$ 테플론 튜브에 넣고, $0.1 \%$ tropolone(Merck, Hohenbrum, Germany)이 함유된 methylene chloride(Merck, Darmstadt, Germany) $20 \mathrm{~mL}$ 와 50\% HCl(Merck, Darmstadt) $10 \mathrm{~mL}$ 를 넣은 후 교반기(mechanical shaker)를 이용

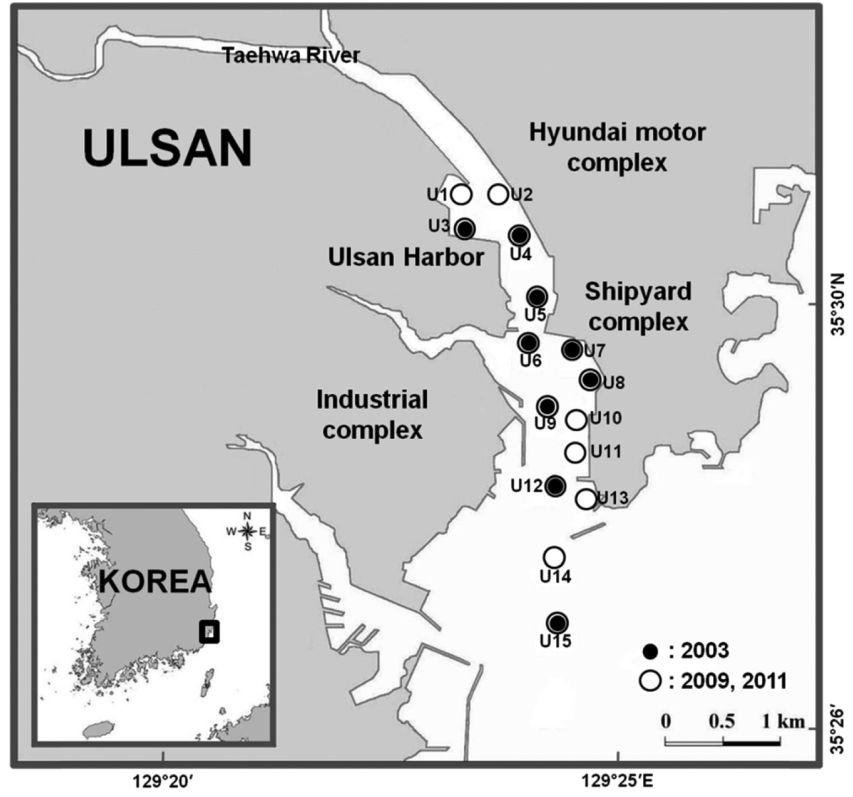

Fig. 1. Sampling locations of marine sediments from Ulsan Bay, in 2003(Choi et al., 2009b), 2009 and 2011.

하여 추출하였다. 내부표준물질로써 tripentyltin chloride(Kanto, Tokyo, Japan)는 추출 전 첨가되었으며, 추출된 시료는 hexane (Merck, Darmstadt, Germany)으로 치환 후 n-hexylmagnesium bromide(TCI, Tokyo, Japan)을 넣고 유도체화하였다. 유도체화 된 시료는 florisil(Sigma-Aldrich, Milwaukee, WI, USA)로 충진된 컬럼으로 방해물질을 제거하였으며, 이후 질소농축하였다. 농축된 시료에 회수율 점검을 위한 내부표준물질(tetrabutyltin, SigmaAldrich)을 첨가하여, GC/MS(GC-6890 series; and MS-5973N; Agilent Technologies, Wilmington, DE, USA)로 분석하였다. GC 용 컬럼은 DB-5MS( $30-\mathrm{m}$ length $\times 0.25$-mm inner diameter $\times 0.25$-mm film thickness; J\&W Scientific, Palo Alto, CA, USA)를 사용하였으며, 상세한 기기분석조건은 또한 Choi et al.(2010)에 제시되어 있다.

퇴적물 내 총유기탄소(total organic carbon; TOC)는 $1 \mathrm{~N} \mathrm{HCl}$ 로 calcium carbonate를 제거한 후, 원소분석기(CHN Elemental Analyzer; model 2400; PerkinElmer, Boston, MA, USA)를 이용하여 정량 하였다.

\section{QA/QC (Quality assurance/quality control)}

$\mathrm{BTs}$ 분석 시, blank, 표준인증물질(PACS-2; NRCC, Guelph, ON, Canada; $1.05 \pm 0.06 \mu \mathrm{g} \mathrm{Sn} \mathrm{g}^{-1}$ of DBT, $0.89 \pm 0.11 \mu \mathrm{g} \mathrm{Sn} \mathrm{g}^{-1}$ of TBT), 그리고 표준물질이 주입된 시료(spiked samples)를 함께 분석하였 다. PACS-2에 대한 분석결과 $(\mathrm{n}=4)$ 는 각각 DBT $1.17 \pm 0.15 \mu \mathrm{g} \mathrm{Sn} \mathrm{g}^{-1}$, TBT $0.75 \pm 0.12 \mu \mathrm{g} \mathrm{Sn} \mathrm{g}^{-1}$ 이었다. Monobutyltin의 회수율은 넓은 범위(40 250\%)을 보여 본 연구의 결과에서 제외하였다. 표준인 증물질과 시료 중 내부표준물질 tripentyltin chloride의 회수율은 $83 \pm 13 \%$ 이었다. 검출한계는 신호 대 잡음 비(Signal to noise: $\mathrm{S} /$ $\mathrm{N}>3$ )을 기초로 계산하였으며, DBT와 TBT는 $0.2 \mathrm{ng} \mathrm{Sn} \mathrm{g}^{-1} \mathrm{dry}$ $\mathrm{wt}$ 이었다. BTs의 모든 단위는 $\mathrm{ng} \mathrm{Sn} \mathrm{g^{-1 }} \operatorname{dry} \mathrm{wt}($ 건중량)로 나타 내었다. 


\section{통계 분석}

울산만 퇴적물 내 $\mathrm{BTs}$ 농도, $\mathrm{POPs}(\mathrm{PCDD} / \mathrm{Fs}, \mathrm{PBDEs}, \mathrm{PCBs})$, $\mathrm{TOC}$ 간 상관성분석은 자료의 로그변환 후 Pearson correlation으로 수행하였다. 조사자료의 정규분포 검정은 Kolmogorov-Smirmoff 와 Shapiro-Wilk test를 이용하여 추정하였고, 조사자료에 대한 농 도값의 차이는 Mann-Whitney U test를 이용하여 추정하였다. 통 계적 유의수준은 $p$-value $<0.05$ 로 하였다. 통계분석은 윈도우용 SPSS software(SPSS 2000)를 이용하여 수행하였다.

\section{결과 및 고찰}

\section{1년 TBT 농도수준 및 공간적 분포}

울산만에서 채취한 퇴적물 내 $\mathrm{TBT}$ 와 DBT 농도는 각각 14.2

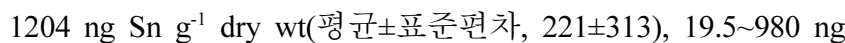
$\mathrm{Sn} \mathrm{g}^{-1}$ dry wt(194 \pm 251$)$ 범위로 나타났다. 퇴적물 내 TBT와 DBT의 농도는 높은 상관성 $(\mathrm{r}=0.909, p<0.001)$ 을 보였으며, 이것은 울산만 내 TBT와 DBT의 공간적 분포가 유사함을 의미한다. 따라서, DBT 는 TBT에 비해 다양한 배출원을 갖지만, 울산만에서 $\mathrm{TBT}$ 와 동일 한 오염원을 갖거나 유사한 거동을 하는 것으로 판단된다(Devier et al., 2005; Fent and Müller, 1991; Hoch, 2001). 한편, $\mathrm{EBTs(DBT}$ 와 $\mathrm{TBT}$ 의 합)와 $\mathrm{TOC}$ 는 낮은 상관계수를 보였으며 $(\mathrm{r}=0.027, p=0.923)$,

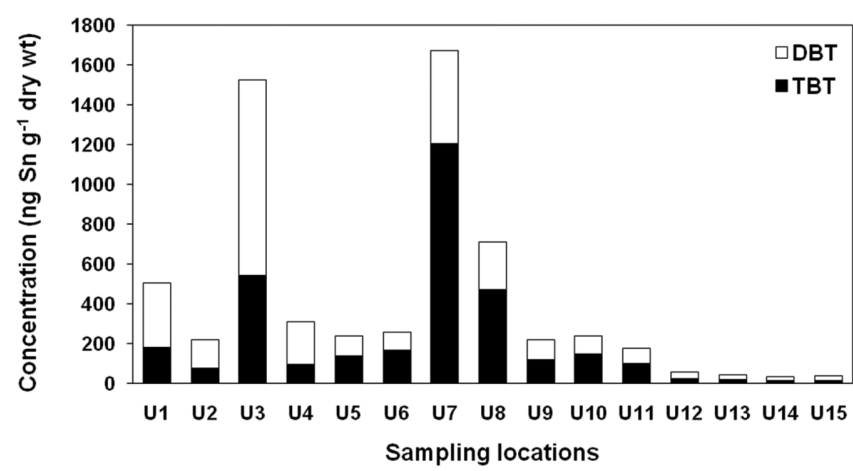

Fig. 2. Spatial distribution of DBT and TBT in marine sediments from Ulsan Bay, Korea.
이것은 울산만 내에서 $\mathrm{TOC}$ 와 $\mathrm{BTs}$ 의 거동 및 분포가 다름을 의미 한다(Choi et al., 2009a).

퇴적물 중 TBT의 최고농도는 조선소 앞 정점 $\mathrm{U} 7\left(1204 \mathrm{ng} \mathrm{Sn} \mathrm{g}^{-1}\right.$ $\mathrm{dry} \mathrm{wt}$ )에서 조사되었고, 평균값 이상을 보인 정점은 울산항 앞 U3 (544 ng Sn g ${ }^{-1}$ dry wt)과 조선소 주변 U8(469 ng Sn g${ }^{-1}$ dry wt) 이었다(Fig. 2). 이것은 항만시설과 조선소 관련 시설물이 TBT의 주요 배출원임을 의미하며, 울산만의 경우 조선소가 가장 중요한 TBT 배출원이었다(Shim et al., 2002; Choi et al., 2010a).

국내외 퇴적물 내 TBT의 잔류수준을 Table 1에 나타내었다. 본 연구의 울산만 퇴적물 내 TBT 최대농도는 2010년 채집된 고현만 퇴적물의 2.6배 높은 수준이었으며(Kim et al., 2011b), 2004년과 2005년의 마산만 퇴적물 내 TBT의 3배 높은 수준이었으며(Kim et al., 2011a), 또한 2008년 군산연안의 잔류수준에 비해 매우 높은 것으로 나타났다(Lee et al., 2012). 항만 및 조선소가 위치한 해 역이 포함된 국외 TBT 연구결과에서, 아시아 국가 중 일본(Harino et al., 2007)과 인도(Garg et al., 2011)의 TBT 최대농도는 본 연 구결과보다 약 10 배나 높았으며, 태국(Harino et al., 2006)은 유 사한 수준이었으며, 말레이시아(Harino et al., 2009)는 울산만 퇴 적물에 비해 낮은 $\mathrm{TBT}$ 농도수준으로 보고되었다. 유럽 국가인 스 페인(Rodríguez et al., 2010)과 포르투갈(Sousa et al., 2007)의 TBT의 최대농도는 울산만의 약 1.5 배 이상 높은 수준이었으며, 브 라질(de Oliveira et al., 2010)의 경우 울산만의 최대농도와 유사 한 수준으로 나타났다. 본 연구와 국내외 선행연구의 비교결과, 울 산만은 국내 다른 연안에 비해 높은 수준이었지만, 조선소 등을 포함한 다른 나라의 연안의 결과와 유사하거나 낮은 수준이었다.

$\mathrm{BTs}$ 의 최근 유입현황을 반영하는 $\mathrm{TBT} / \mathrm{DBT}$ 비율을 조사한 결 과(Choi et al., 2010a), 울산만 퇴적물은 0.4 2.6(1.1 \pm 0.6$)$ 의 범위로 나타났다. 울산만 15 개 정점 중 TBT/DBT 비율의 평균값보다 높게 나타난 정점은 U5 U11이며, 특히 U7에서 가장 높은 비율로 조사 되었다. TBT 농도와 $\mathrm{TBT} / \mathrm{DBT}$ 비율간의 상관계수는 $0.649(p<0.01)$ 을 보여 $\mathrm{TBT}$ 농도가 높은 정점에서 $\mathrm{TBT} / \mathrm{DBT}$ 비율도 높았다. 이 러한 결과는 기존에 보고된 연구결과(Bhosle et al., 2006; Diez et al. 2006; Berto et al., 2007)와도 일치하였다. 이것은 항구 및 조 선소와 같은 hotspot에서 BTs의 많은 유입량과 $\mathrm{TBT}$ 의 낮은 분해

Table 1. Concentrations of TBT in marine sediments form this study and some locations in other countries

\begin{tabular}{lccc}
\hline \hline Location & Sampling year & TBT (ng Sn g ${ }^{-1}$ dry wt) & Reference \\
\hline Ulsan Bay & 2011 & $14-1,204$ & This study \\
Gohyeon Bay & 2010 & $20-469$ & Kim et al., 2011b \\
Masan Bay & $2004-2005$ & $6-165$ & Kim et al., 2011a \\
Gunsan Coast & 2008 & $<$ LOD $^{\mathrm{a}-1}$ & Lee et al., 2012 \\
Other countries & & & \\
Otsuchi Bay, Japan & 2005 & $\mathrm{ND}^{\mathrm{b}}-14,000$ & Harino et al., 2007 \\
Thailand Coast & 2004 & $2-1,246$ & Harino et al., 2006 \\
Malaysia Coast & 2006 & $1-940$ & Harino et al., 2009 \\
India Coast & 2008 & $<$ LOD-14,861 et al., 2011 \\
Port of Pasaia, Spain & 2007 & $16-3,132$ & Rodríguez et al., 2010 \\
Port of Bilbao, Spain & 2008 & $0-3,143$ & Sousa et al., 2007 \\
Ria de Aveiro, Portugal & 2005 & $2-1,780$ & de Oliveira et al., 2010 \\
Santa Catarina harbor regions, Brazil & 2008 & ND-1,137 &
\end{tabular}

${ }^{\mathrm{a}}$ Less than limit of detection; ${ }^{\mathrm{b}}$ Not detected. 

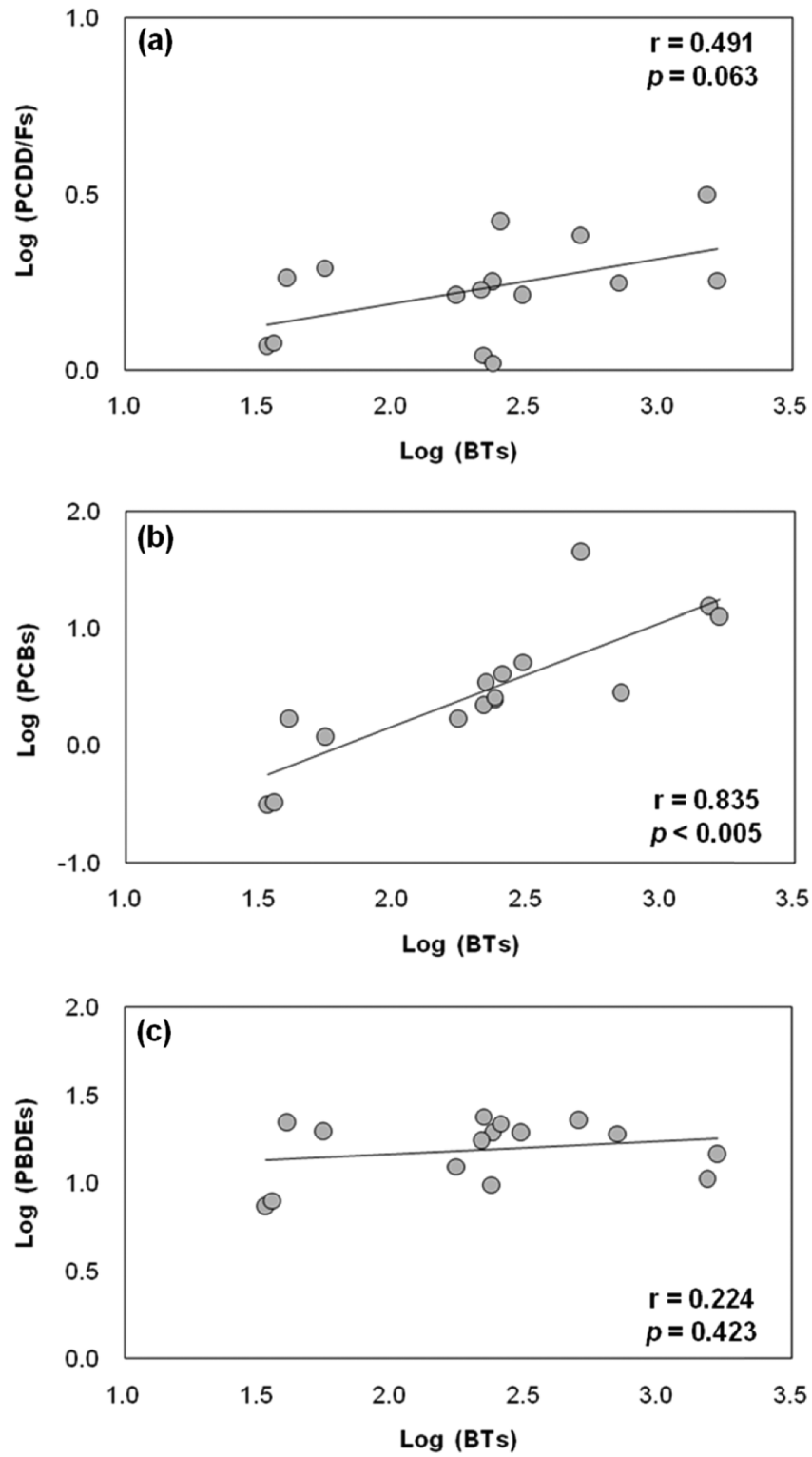

Fig. 3. Correlation between BTs and (a) polychlorinated dibenzo- $p$-dioxins and furans (PCDD/Fs), (b) polychlorinated biphenyls (PCBs), (c) polybrominated diphenyl ethers (PBDEs) in marine sediments from Ulsan Bay, Korea.

율과 관련이 있다. Burton et al.(2005, 2006)의 보고에 따르면, $\mathrm{TBT}$ 는 퇴적물의 미세입자와 쉽게 흡착하기 때문에 일단 퇴적물 로 유입하면, 공극수의 용존상 또는 퇴적물에서 탈착량이 낮아 생 물학적 분해가 어렵다. 이와 함께, 퇴적물에 BTs 함유 페인트 입 자가 존재한다면, 생물학적 분해가 더욱 느려지는 것으로 보고된 다(Diez et al., 2006; Berto et al., 2007). 따라서 오염된 퇴적물 에서 BTs는 규제 이후에도 오랫동안 검출될 수 있다. 항구 및 조 선소가 위치한 해역에 대한 국외 연구결과와 비교 시, 울산만에서

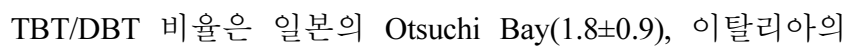

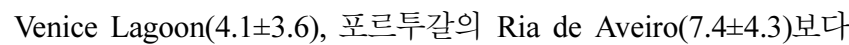
낮게 나타났다(Berto et al., 2007; Harino et al., 2007; Sousa et al., 2007). 따라서, 울산만에서 TBT에 대한 최근의 유입정도는 외국
에 비해 낮은 수준인 것으로 추정된다.

울산만의 동일 퇴적물에서 분석한 $\mathrm{PCDD} / \mathrm{Fs}, \mathrm{PBDEs}, \mathrm{PCBs}$ 의 농도(백 등, 2013)와 BTs와의 상관성을 분석하였다(Fig. 3). 상관 성 분석결과, $\mathrm{BTs}$ 는 $\mathrm{PCBs}$ 와 가장 높은 상관성을 나타내었다 $(\mathrm{r}=0.835, p<0.005)$. 백 등(2013)의 연구결과에서, 울산항 주변(U1, $\mathrm{U} 3)$ 과 조선소 앞(U7) 정점에서 $\mathrm{PCBs}$ 농도는 모든 정점의 평균농 도보다 2 배 이상으로 크게 오염되어있었다. 이것은 BTs의 주요배 출원인 항만 및 조선소로부터 PCBs 가 배출되는 것을 의미한다. 이것은 Hong et al.(2005)의 연구와도 일치하는 것으로, 선박시설 에서 PCBs가 첨가된 페인트 및 절연체의 사용에 따른 오염으로 판단된다. 따라서, 울산만에서 항만과 조선소 등 선박활동과 관련 한 시설물은 $\mathrm{BTs}$ 의 배출원임과 동시에 $\mathrm{PCBs}$ 물질의 오염원으로 작용할 수 있으므로, 조선소 등 다양한 선박활동해역에서 BTs조 사와 함께 $\mathrm{PCBs}$ 에 대한 연구수행의 필요할 것으로 판단된다.

\section{시간적 분포}

국내 연안 내 시료별 시간변화에 따른 TBT 농도 수준을 Table 2 에 나타내었다. TBT의 사용규제 이후, 국내 연안 내 해수와 생 물시료에서 농도 감소하는 경향이 나타났으나(Shim et al., 2005; Choi et al., 2009b, 2010a), 퇴적물 시료에서는 TBT 감소경향이 뚜렷하지 않은 것으로 보고되었다(Choi et al., 2009b; Kim et al., 2011b). 퇴적물에서 TBT가 장기적으로 검출되는 원인은 해수와 패류에 비해 BTs의 긴 반감기 때문으로, Dowson et al.(1993)는 해수 중 TBT의 반감기는 3 15일이며 퇴적물의 반감기는 수개월 에서 8년까지인 것으로 보고한 바 있다.

본 연구에서 2003(Choi et al., 2009a), 2009, 2011년 울산만 퇴 적물 시료 내 $\mathrm{BTs}$ 의 잔류농도수준은 감소하는 경향을 보였다(Fig. 4a). 2003년의 퇴적물 내 DBT, TBT 농도수준은 각각 $461 \mathrm{ng} \mathrm{Sn} \mathrm{g}^{-1}$ dry wt, $818 \mathrm{ng} \mathrm{Sn} \mathrm{g}^{-1}$ dry wt으로 나타났다. 2009년과 2011년의 DBT 평균농도는 각각 2003 년의 $30 \%, 48 \%$ 수준으로 나타났으며, TBT 농도의 경우 2003 년의 $43 \%, 31 \%(p<0.05)$ 수준으로 감소하 였다. 또한, 2009년과 2011년의 BTs 농도수준은 각각 2003년의 $38,37 \%$ 수준으로 뚜렷한 감소의 경향을 보였다 $(p<0.05)$.

울산만 퇴적물 내 BTs 농도감소는 TBT 규제에 따른 BTs 유입 량 감소와 울산만의 낮은 내만도와 같은 지리적 특성과 관련 있 을 것으로 생각된다. 울산항의 선박입출항 자료(2000 2011년)에 따르면(통계청 홈페이지), 입출항 선박수는 2000 년 이후에 매년 48,000 척 이상을 보였고, 2003년 이후에는 50,000 척 이상으로 증 가하였다. 그리고 입출항 선박의 총 톤수는 연도별로 증가의 경향 을 보였다(Fig. 5). 입출항 선박수의 증가와 달리, BTs 농도감소는 규제효과로 인해 해양으로 BTs 유입량이 감소한 것으로 판단된다. 게다가, 동해안에 위치한 울산만은 국내 다른 만에 비해 비교적 수심이 깊고 개방적인 형태로 해수의 순환이 원활한 만으로(김동 명, 2011), 반폐쇄성 만 또는 내만도가 높은 연안보다 오염물질 유 입량 감소의 효과를 잘 반영하는 것으로 판단된다. 특별관리해역 인 울산만, 마산만, 시화호에 대한 퇴적물오염도의 평가결과에서 (Choi et al., 2010b), 울산만은 국내에서 가장 많은 생산량과 수출 량의 산업단지가 해안선을 따라 위치하고 있음에도 불구하고, 내 만도가 높은 마산만과 시화호에 비해 매우 낮은 퇴적물오염도 (TOC, 산휘발성 황화합물, 중금속, 퇴적물 독성도)를 보였다. 따라 
Table 2. Temporal variations of TBT in seawater, sediments, and bivalves from the coastal environment of Korea

\begin{tabular}{|c|c|c|c|c|c|c|}
\hline Location & Chemical & $\begin{array}{c}\text { Sampling } \\
\text { year }\end{array}$ & $\begin{array}{l}\text { Seawater } \\
\left(\text { ng Sn L }^{-1}\right)\end{array}$ & $\begin{array}{c}\text { Bivalves } \\
\text { (ng Sn g }{ }^{-1} \text { dry wt) }\end{array}$ & $\begin{array}{l}\text { Marine sediments } \\
\left(\text { ng Sn g }{ }^{-1} \text { dry wt) }\right.\end{array}$ & Reference \\
\hline Busan & $\mathrm{DBT}+\mathrm{TBT}$ & 2002 & $9-102$ & $640-3,801$ & $15-6,107$ & Choi et al., 2010a \\
\hline Harbor & & 2007 & $1-49(9)^{\mathrm{a}}$ & $162-1,166(531)$ & $4-2,980(223)$ & \\
\hline \multirow[t]{3}{*}{ Gohyeon Bay } & TBT & 2007 & - & - & $\mathrm{ND}^{\mathrm{b}}-684(154 \pm 264)^{\mathrm{c}}$ & Kim et al., 2011b \\
\hline & & 2008 & - & - & $18-762(191 \pm 288)$ & \\
\hline & & 2010 & - & - & $20-469(125 \pm 174)$ & \\
\hline \multirow{4}{*}{$\begin{array}{c}\text { Korean coastal } \\
\text { areas }\end{array}$} & DBT & $1995-1998$ & - & $27-1,950(170 \pm 290)^{\mathrm{c}}$ & - & Shim et al., 2005 \\
\hline & & 2001 & - & $<3-1,710(266 \pm 409)$ & - & \\
\hline & TBT & $1995-1998$ & - & $48-2,800(566 \pm 573)$ & - & \\
\hline & & 2001 & - & $32-2,460(491 \pm 534)$ & - & \\
\hline \multirow{5}{*}{$\begin{array}{c}\text { Korean coastal } \\
\text { areas }\end{array}$} & TBT & 2001 & $<\operatorname{LOD}^{\mathrm{d}}-164(25)^{\mathrm{e}}$ & $132-6,296(1,111)$ & $<$ LOD-715(100) & Choi et al., 2009b \\
\hline & & 2002 & $<$ LOD-144(23) & $61-2,889(505)$ & $<$ LOD-9,576(551) & \\
\hline & & 2003 & $<$ LOD-110(64) & $20-5,260(416)$ & $<$ LOD-348(69) & \\
\hline & & 2004 & $<$ LOD-24(2) & $21-734(151)$ & $<$ LOD-630(102) & \\
\hline & & 2005 & $<\mathrm{LOD}$ & $<$ LOD-767(92) & $<$ LOD-782(70) & \\
\hline
\end{tabular}

${ }^{\mathrm{a}}$ Median value; ${ }^{\mathrm{b}}$ Not detected; ${ }^{\mathrm{C}}$ Mean \pm standard deviation; ${ }^{\mathrm{d}}$ Less than limit of detection; ${ }^{\mathrm{e}}$ Mean value.

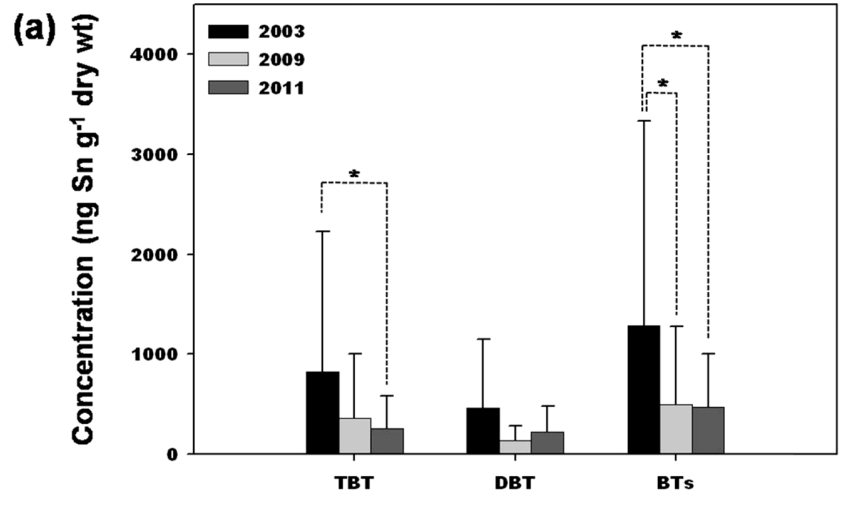

(b)

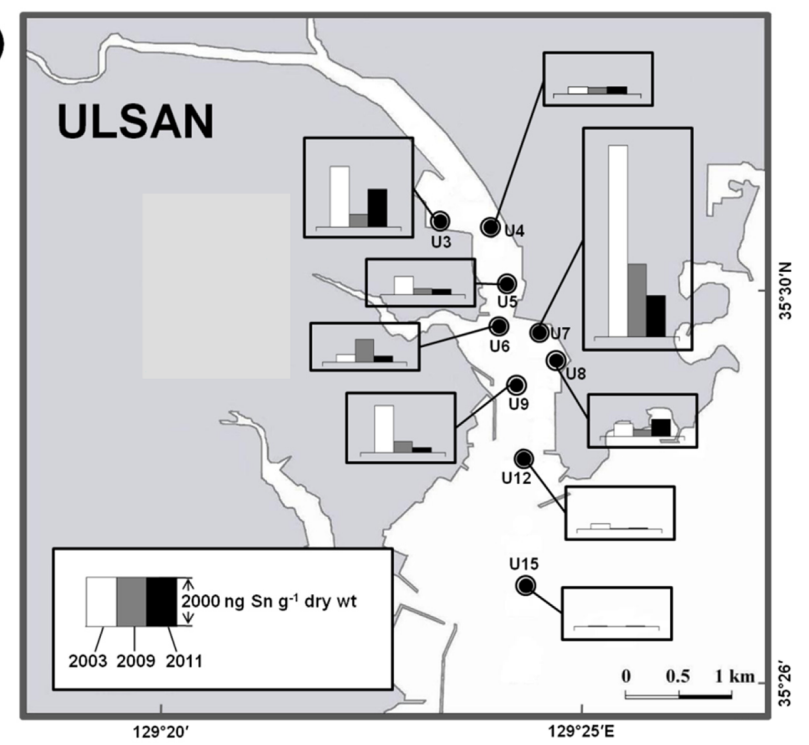

Fig. 4. Temporal variation of TBT, DBT, and BTs in Ulsan Bay sediments in 2003(Choi et al., 2009b), 2009 and 2011 surveys (9 Samples in the inner bay). ${ }^{*} p<0.05$.

서 울산만은 국내 다른 연안에 비해 BTs의 규제가 더 효과적인 것 으로 판단된다.

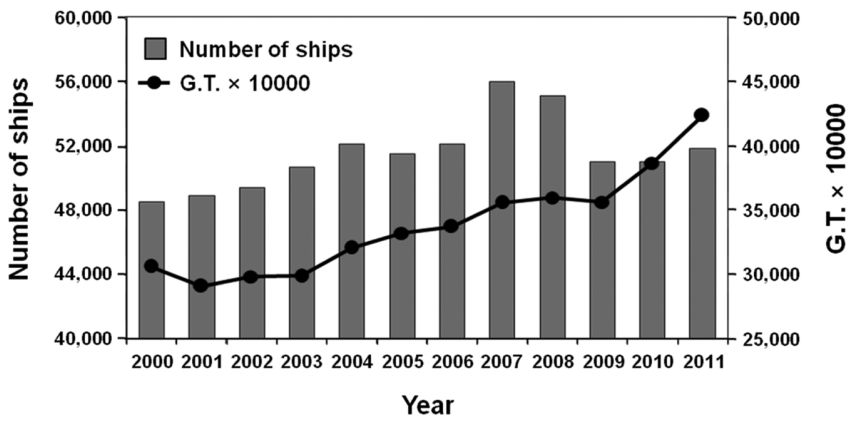

Fig. 5. Numbers of ships entered in Ulsan Harbor between 2000 and 2011. G.T. indicates total gross tonnage (http://kostat.go.kr/wnsearch/ search.jsp).

시간에 따른 해양 퇴적물 내 $\mathrm{TBT}$ 의 감소패턴은 Díez et al. (2006), Lahbib et al.(2011)의 연구결과에서 보고되었으며, 퇴적물 내 TBT 잔류의 감소경향을 BTs의 사용 및 배출 금지에 따른 BTs 의 해양 유입의 감소의 결과로 보고하였다. 본 연구에서도 2011년 울산항(U3)과 조선소(U7) 퇴적물 내 TBT 농도는 각각 2003년의 $58,22 \%$ 수준으로 나타나 울산만의 감소경향을 주도하였다(Fig. 4b). 또한, 울산만에서 TBT/DBT 비율은 2003, 2009, 2011년 시 료에서 각각 $2.3 \pm 1.6,2.0 \pm 1.3,1.3 \pm 0.8$ 로 감소하는 경향을 보여서 울산만 퇴적물 내 $\mathrm{TBT}$ 의 잔류량 감소를 잘 반영하였다.

\section{생태독성 및 국외기준 비교}

2009, 2011년에 울산만 퇴적물 내 TBT 농도는 모든 정점에서 오스트레일리아의 퇴적물 내 TBT 하위기준(low trigger value, $5 \mathrm{ng}$ $\mathrm{Sn} \mathrm{g}^{-1} \mathrm{dry} \mathrm{wt}$ ) 이상이었으며, 정점의 $60 \%$ 이상이 상위기준(high trigger value, $70 \mathrm{ng} \mathrm{Sn} \mathrm{g}^{-1} \mathrm{dry} \mathrm{wt}$ )를 초과한 수준으로 높게 나타 났다(Fig. 6). 또한, 각 연도의 TBT 농도는 저서생물(amphipods, polychaetes)에 만성독성을 나타내는 농도(42 ng Sn g ${ }^{-1} \mathrm{dry} \mathrm{wt}$ 를 초과한 정점은 조사정점의 $60 \%$ 로 나타났으며(Matthiessen and Thain, 1989), 2011년의 경우 퇴적물 잠입성 패류(deposit-feeding 


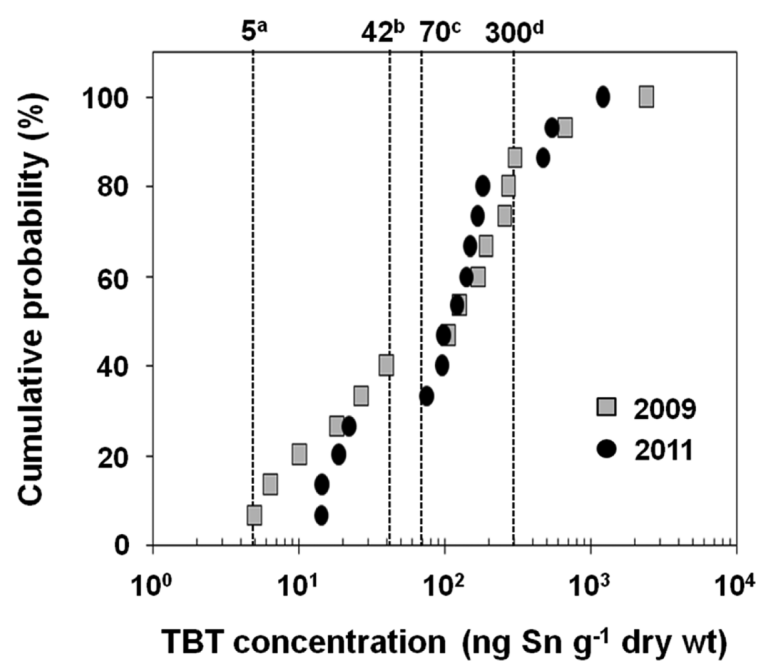

Fig. 6. Cumulative probability of TBT concentrations in sediment samples from Ulsan Bay, Korea. ${ }^{a}$ Australian sediment quality guideline low trigger value (Burton et al., 2005); ${ }^{b}$ Chronic effects on amphipods

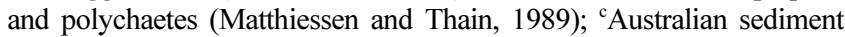
quality guideline - high trigger value (Burton et al., 2005); ${ }^{\mathrm{d}}$ Chronic effects on clam (Langstone and Burt, 1991; Ruiz et al., 1996).

clam, Sorbicularia plana)에 만성독성을 유발할 수 있는 농도(300 $\mathrm{ng} \mathrm{Sn} \mathrm{g^{-1 }}$ dry wt)보다 높은 정점이 3개나 조사되었다(Langstone and Burt, 1991; Ruiz et al., 1996). 울산만 퇴적물의 농도수준은 시간에 따라 감소하는 경향이었으나 독성유발농도 및 국외기준을 초과하는 정점들이 상당히 존재하므로, 울산만 퇴적물 중 $\mathrm{BTs}$ 에 대한 지속적인 모니터링 및 농도저감을 위한 노력이 필요한 것으 로 판단된다.

\section{결 론}

울산만 퇴적물에 대한 $\mathrm{BTs}$ 분석결과, $\mathrm{DBT}$ 와 $\mathrm{TBT}$ 는 높은 상관 성을 보였으며, 울산만 내 퇴적물에 대한 BTs의 주요 오염원은 조 선소와 항만으로 나타났다. 선행연구와 비교에서 울산만 퇴적물의 잔류수준은 국내 다른 해역에 비해 높게 나타났으며, 조사된 국외 항만 및 조선 시설이 위치한 해역에 비해 양호한 수준이었다. 또 한, $\mathrm{POPs}$ 물질과 $\mathrm{BTs}$ 의 상관성 분석결과를 통하여 조선소와 항만은 BTs 뿐만 아니라 PCBs로도 오염되어 있음을 확인하였다. 2003, 2009, 2011년 울산만 퇴적물 시료에 대한 BTs의 잔류농도수준은 감소하는 경향을 보였으며, 이것은 $\mathrm{TBT}$ 의 국내 사용규제 및 저감 노력에 의한 결과이며, 더불어 울산만의 개방적인 지리적 특성 및 원활한 해수순환의 영향으로 추정된다. 울산만 퇴적물 내 TBT 농 도는 감소추세를 보였지만, 외국에서 보고된 퇴적물 기준과 만성독 성값을 크게 초과하기 때문에 울산만 퇴적물 내 TBT 농도가 기준 치 이하로 감소할 때까지 지속적인 저감노력과 모니터링이 필요하다.

\section{사 사}

본 연구는 국립수산과학원(RP-2013-ME-084)의 연구지원에 의 해 수행되었습니다.

\section{참고문헌(References)}

김동명, 2011. EMT-3D 모델을 이용한 울산만 Dioxins 거동에 관한 시나리오 분석. 해양환경안전학회지, 17: 89-96.

백승홍, 이인석, 최민규, 황동운, 김숙양, 최희구, 2013. 울산만 퇴 적물 내 $\mathrm{PCDDs}, \mathrm{PCDFs}, \mathrm{DL}-\mathrm{PCBs}$, PBDEs의 잔류수준과 분포패턴. 한국해양학회지, 18: 186-194.

울산광역시청 홈페이지, http://www.ulsan.go.kr/executive/page/ statistics_01.jsp?mNum=4 \&sNum=5\&PGM_GBN=ulsantoday (accessed 17 January 2013).

통계청 홈페이지, http://kostat.go.kr/wnsearch/search.jsp (accessed 11 March 2013).

홍상희, 심원준, 이수형, 이인숙, 2001. 옥포만 내 퇴적물, 해수 및 참굴 중의 유기주석 화합물의 분포. 한국생태학회지, 24: 19-26.

Berto, D., M. Giani, R. Boscolo, S. Covelli, O. Giovanardi, M. Massironi and L. Grassia, 2007. Organotins (TBT and DBT) in water, sediments, and gastropods of the southern Venice lagoon (Italy). Mar. Pollut. Bull., 55: 425-435.

Bhosle, N.B., A. Garg, R. Harji, S. Jadhav, S.S. Sawant, V. Krishnamurthy and C. Anil, 2006. Butyltins in the sediments of Kochi and Mumbai harbours, west coast of India. Environ. Int., 32: 353-258.

Burton, E.D., I.R. Phillips and D.W. Hawker, 2005. In-situ partitioning of butyltin compounds in estuarine sediments. Chemosphere, 59: 585-592.

Burton, E.D., I.R. Phillips and D.W. Hawker, 2006. Tributyltin partitioning in sediments: effect of aging. Chemosphere, 63: 73-81.

Choi, H.-G., H.-B. Moon, M. Choi and J. Yu, 2011. Monitoring of organic contaminants in sediments from the Korean coast: Spatial distribution and temporal trends (20012007). Mar. Pollut. Bull., 62: 1352-1361.

Choi, M., H.-B. Moon, J. Yu, J.-Y. Eom and H.-G. Choi, 2009a. Butyltin Contamination in Industrialized Bays Associated with Intensive Marine Activities in Korea. Arch. Environ. Contam. Toxicol., 57: 77-85.

Choi, M., H.-G. Choi, H.-B. Moon and G.-Y. Kim, 2009b. Spatial and temporal distribution of tributyltin (TBT) in seawater, sediments and bivalves from coastal areas of Korea during 2001-2005. Environ. Monit. Assess., 151: 301-310.

Choi, M., H.-B. Moon, J. Yu, J.-Y. Eom and H.-G. Choi, 2010a. Temporal trend of butyltins in seawater, sediments, and mussels from Busan Harbor of Korea between 2002 and 2007: Tracking the effectiveness of tributylin regulation. Arch. Environ. Contam. Toxicol., 58: 394-402.

Choi, M., G.-S. Kim, S.-P. Yoon, R.-H. Jung, H.-B. Moon, J. Yu and H.-G. Choi. 2010b. Sediment Toxicity of Industrialized Coastal Areas of Korea Using Bioluminescent Marine Bacteria. Korea. Fish. Aquat. Sci., 13: 244-253.

de Oliveira, C.R., D.M. dos Santos, L.A. dos Santos Madureira and M.R.R. de Marchi, 2010. Speciation of butyltin derivatives in surface sediments of three southern Brazilian harbors. J. Hazard. Mater., 181: 851-856.

Devier, M.H., S. Augagneur, H. Budzinski, K. Le Menach, P. Mora, J.F. Narbonne and P. Garrigues, 2005. One-year monitoring survey 
of organic compounds (PAHs, PCBs, TBT), heavy metals and biomarkers in blue mussels from the Arcachon Bay, France. J. Environ. Monit., 7: 224-240.

Díez, S., E. Jover, J. Albaigés and J.M. Bayona, 2006. Occurrence and degradation of butyltins and wastewater marker compounds in sediments from Barcelona harbor, Spain. Environ. Int., 32: 858-865.

Dowson, P.H., J.M. Bubb, T.P. Williams and J.N. Lester, 1993. Degradation of tributyltin in freshwater and estuarine marina sediments. Water Sci. Technol., 28: 133-137.

Fent, K. and M.D. Müller, 1991. Occurrence of organotins in municipal wastewater and sewage sludge and behavior in a treatment plant. Environ. Sci. Technol., 25: 489-493.

Garg, A., R.M. Meena, S. Jadhav and N.B. Bhosle, 2011. Distribution of butyltins in the waters and sediments along the coast of India. Mar. Pollut. Bull., 62: 423-431.

Harino, H., M. Ohji, G. Wattayakorn, T. Arai, S. Rungsupa and N. Miyazaki, 2006. Occurrence of Antifouling Biocides in Sediment and Green Mussels from Thailand. Arch. Environ. Contam. Toxicol., 51: $400-407$.

Harino, H., T. Arai, M. Ohji, A.B. Ismail and N. Miyazaki, 2009. Contamination Profiles of Antifouling Biocides in Selected Coastal Regions of Malaysia. Arch. Environ. Contam. Toxicol., 56: 468478.

Harino, H., Y. Yamamoto, S. Eguchi, S. Kawai, Y. Kurokawa, T. Arai, M. Ohji, H. Okamura and N. Miyazaki, 2007. Concentrations of Antifouling Biocides in Sediment and Mussel Samples Collected from Otsuchi Bay, Japan. Arch. Environ. Contam. Toxicol., 52: 179-188.

Hoch, M., 2001. Organotin compounds in the environment - an overview. Applied Geochemistry, 16: 719-743.

Hong, S.H., U.H. Yim, W.J. Shim and J.R. Oh, 2005. Congener-Specific Survey for Polychlorinated Biphenlys in Sediments of Industrialized Bays in Korea: Regional Characteristics and Pollution Sources. Environ. Sci. Technol., 39: 7380-7388.

International Maritime Organization (IMO), 2009, International convention on the control of harmful anti-fouling systems on ships, 2001.

Kim, N.S., S.Y. Ha, J.G. An, U.H. Yim, S.H. Hong, M. Kim, N. Kannan and W.J. Shim, 2011a. Status and Trend of Butyltin Contamination in Masan Bay, Korea. Toxicol. Environ. Health Sci., 3: $46-53$.

Kim, N.S., W.J. Shim, U.H. Yim, S.Y. Ha, J.G. An and K.H. Shin, 2011b. Three decades of TBT contamination in sediments around a large scale shipyard. J. Hazard. Mater., 192: 634-642.

Lahbib, Y., S. Abidli, P.R. González, J.G. Alonso and N.T.E. Menif, 2011. Monitoring of Organotin Pollution in Bizerta Channel (Northern Tunisia): Temporal Trend from 2002 to 2010). Bull. Environ. Contam. Toxicol., 86: 531-534.

Langstone, W.J. and G.R. Burt, 1991. Bioavailability and effects of sediment-bound TBT in deposit-feeding clams, Sorbicularia plana. Mar. Environ. Res., 32: 61-77.

Lee, W.-S., M. Choi, D.-W. Hwang, I.-S. Lee and S.Y. Kim. 2012. Chemical Contamination and Toxicity of Sediments from the Gunsan Coast, Korea. Fish. Aquat. Sci., 15: 241-250.

Matthiessen, P. and J.E. Thain, 1989. A method for studying the impact of polluted marine sediments on intertidal colonising organisms; tests with diesel-based drilling mud and tributyltin antifouling paint. Hydrobiologia. 188/189: 477-485.

Ministry of Maritime Affairs and Fisheries (MOMAF), 2002. Domestic plans for Anti-Fouling System Convention in International Maritime Organization (IMO).

Ruiz, J.M., G. Bachelet, P. Caumette and O.F.X. Donard, 1996. Three decades of tributyltin in the coastal environment with emphasis on Arcachon Bay, France. Environ. Pollut., 93: 195-203.

Rodríguez, J.G., O. Solaun, J. Larreta, M.J.B. Segarra, J. Franco, J.I.G. Alonso, C. Sariego, V. Valencia and Á. Borja, 2010. Baseline of butyltin pollution in coastal sediments within the Basque Country (northern Spain), in 2007-2008. Mar. Pollut. Bull., 60: 139-151.

Shim, W.J., S.H. Hong, N.S. Kim, U.H. Yim, D. Li and J.R. Oh, 2005. Assessment of butyl- and phenyltin pollution in the coastal environment of Korea using mussels and oysters. Mar. Pollut. Bull., 51: 922-931.

Shim, W.J., S.H. Hong, U.H. Yim, N.S. Kim and J.R. Oh, 2002. Horizontal and Vertical Distribution of Butyltin Compounds in Sediments from Shipyards in Korea. Arch. Environ. Contam. Toxicol., 43: $277-283$.

Sousa, A., C. Matsudaira, S. Takahashi, S. Tanabe and C. Barroso, 2007. Integrative assessment of organotin contamination in a southern European estuarine system (Ria de Aveiro, NW Portugal): Tracking temporal trends in order to evaluate the effectiveness of the EU ban. Mar. Pollut. Bull., 54: 1645-1653.

2013년 9월 5일 원고접수

2013년 11월 19일 수정본 접수

2013년 12월 18일 수정본 채택

담당편집위원: 최만식 